\title{
Evaluation of the Competitiveness of China's Liquor Enterprise Based on Factor Analysis Method
}

\author{
Jie Yao, Tongqiang Liu \\ School of Economy and Management, \\ Northeast Dianli University, \\ Jilin, China
}

\begin{abstract}
In 2011, the output of liquor industry in our country is nearly four hundred billion RMB yuan and the market scale is nearly two hundred billion RMB yuan. The main reason for the liquor-making industry to develop is that the increasing of people's incomes has led to the escalating of consumption. At the same time, the development of liquor industry has changed so much. For example, the internal industrial structure has changed and the low-end market of liquor industry has begun to decline. On the contrary, the scale of high-end liquor market has made a spurt of progress. With the increase of Liquor market scale and the changes of internal structure, a large number of liquor enterprises have come to the fore. Lu Zhou Lao Jiao, Yanghe River Shares, Shui Jing Fang, and some other liquor enterprises have developed to be the new forces that can compete against the old overlord of the liquor market such as Gui Zhou Mao Tai and Wu Liang Ye. But at the same time, with the market scale becoming stable gradually, the intense competition in the liquor industry will heat up. The old overlord such as Mou Tai and Wu Liang Ye will actively seize the new market on the basis of stabilizing the current market. And the new forces such as Lu Zhou Lao Jiao and the Yanghe River Shares will also inevitably try to seize the new market for its own development. So the serious competition cannot be avoided. If the liquor enterprise wants to survive in the fierce competition, it must own enough competitiveness. Improving their own competitiveness is the main task for the liquor enterprises to do now. This paper has used factor analysis method to evaluate the competitiveness of the ten well-known liquor enterprises. And it has analyzed the scale index, the effectiveness index and growth index of these enterprises which reflect the competitiveness of enterprises by using statistical software SPSS. Finally, we got the ranking of the two principal component and overall competitiveness, and then made in-depth analysis of the main factors that affect the competitiveness of these liquor companies in order to provide some ideas for improving the competitiveness of liquor enterprises.
\end{abstract}

Keywords-factor analysis; competitiveness evaluation; the liquor enterprise

\section{INTRODUCTION}

The competitiveness of enterprises refers to a kind of comprehensive ability through which the enterprise cultivates its own resources and capabilities, gets access to external resources and realizes its own value on the basis of creating value for customers [1]. At the same time, it is also a kind of comprehensive quality with which the enterprise can provide products and services to the market more effectively than other enterprises, gain profit, and realize self-development. How to evaluate the competitiveness of an enterprise is a special issue of the research on competitiveness. From the point of the research value of competitiveness, we should not only use the method of economics and management to study competitiveness but also use statistical methods $[2,3]$ to express it.

The knowledge of economics and management used to be a conventional method to evaluate competitiveness. All enterprises are rational and good at premeditating. They all make decisions and take actions according to the principle and method of microeconomics with the assumption of rational man as the foundation and with the enterprises' homogenous quality as the basic logical premise [4]. Therefore, in the field of economics the essence of the competitiveness depends on the economic efficiency or productivity. And this determines that the economic research work on competitiveness is mainly focused on the cost and price differentiation [5]. With the development of economic theory, the research on the competitiveness of enterprises extends to the entrepreneurs' innovative ability and risk-taking ability with the introduction of uncertainty [6]. If the research on competitiveness goes deep into the interior of enterprises and enters the field of management and economics, then a kind of research paradigm which is a combination of economics and management will be formed. When we go deep into the research on some primary factors of the competitiveness, namely when we discuss about the core competence of enterprises, such factors as values, culture, irrational factors and so on will be introduced into the research field of competitiveness which is not mentioned by traditional economics[7].

However, competitiveness is a very complex concept. Whether from the point of economics or from the point of management to analyze, the connotation and extension of competitiveness are both difficult to be defined precisely. Therefore, from the research value of competitiveness, it should not only be studied through the method of economics and management but also be expressed through the method of statistics. Economics is used to make clear the nature of competitiveness based on rigorous deductive logic. Management is used to find the actual determinants of competitiveness in reality [8]. Thus, the nature and elements of enterprises' competitiveness can get their theoretical and empirical explanations. Then some rea- 
sonable quantitative indexes are set to evaluate the competitiveness of enterprises through statistic method.

\section{CONSTRUCTION OF THE INDEX SYSTEM USED FOR EVALUATING THE COMPETITIVENESS OF LIQUOR ENTERPRISE}

Some factors affecting the competitiveness of enterprises come from the outside of an enterprise [9], and some of them come from the inside of an enterprise. And they can be divided into economic factors and noneconomic factors [10]. But non-economic factors are difficult to evaluate. So the indexes selected to evaluate the competitiveness of enterprises should be those economic indicators that are easy for statistics and collection.

Usually when evaluating the competitiveness of enterprises, we select those factors including profitability index, solvency index, growth index, scale index, operational index, and so on. Although selecting more indicators means that the evaluation of the competitiveness of enterprises will be more comprehensive, but too many indicators tend to hide a number of substantive issues and will bring difficulties to the actual research. Combined with the characteristics of China's liquor industry and based on the previous research, this paper argues that the scale of the enterprise has great impact on its competitiveness in China. It is often related with the relations between the enterprise and the government [11, 12] and with the corporate social image. And then, the growth index is also very important. The relatively short life period of enterprises directly leads to the lack of competitiveness, which affects the long-term development of the enterprise during its growth stage. Finally, this article selects the profitability indicators. Whether an enterprise can gain profit or not is related to whether it can survive in the market competition. Therefore, the following three kinds of factors are selected to be the evaluating index system to evaluate the competitiveness of enterprises. They are scale index, growth index, and profitability index, which have been shown in Table I.

TABLE I. EVALUATION INDEX SYSTEM OF LIQUOR ENTERPRISE' COMPETITIVENESS.

\begin{tabular}{|c|c|}
\hline Factors & Specific Indicators \\
\hline \multirow{4}{*}{$\begin{array}{r}\text { Scale index } \\
(1,000,000 \\
\text { RMB yuan })\end{array}$} & Sales income \\
\hline & Net profit \\
\hline & Total profit \\
\hline & Net assets \\
\hline \multirow{2}{*}{$\begin{array}{l}\text { Growth } \\
\text { index } \\
(\%)\end{array}$} & $\begin{array}{c}\text { Average growth rate of sales revenue for the last three } \\
\text { years }\end{array}$ \\
\hline & $\begin{array}{c}\text { Average growth rate of net profit for the last three } \\
\text { years }\end{array}$ \\
\hline \multirow{2}{*}{$\begin{array}{l}\text { Profitability } \\
\text { index }(\%)\end{array}$} & Return on net assets \\
\hline & Return on total assets \\
\hline
\end{tabular}

\section{APPLICATION OF FACTOR ANALYSIS METHOD IN} EVALUATING THE COMPETITIVENESS OF ENTERPRISES

TABLE II. EIGENVALUE AND CONTRIBUTION RATE OF VARIANCE.

\begin{tabular}{|c|c|c|c|}
\hline $\begin{array}{c}\text { Principal } \\
\text { Component }\end{array}$ & Eigenvalue & $\begin{array}{c}\text { Contribution } \\
\text { Rate of } \\
\text { Variance }\end{array}$ & $\begin{array}{c}\text { Cumulative } \\
\text { Contribution } \\
\text { Rate of } \\
\text { Variance }\end{array}$ \\
\hline 1 & 4.980 & 62.250 & 62.250 \\
\hline 2 & 1.822 & 22.770 & 85.020 \\
\hline 3 & .824 & 10.302 & 95.322 \\
\hline 4 & .244 & 3.056 & 98.378 \\
\hline 5 & .087 & 1.090 & 99.468 \\
\hline 6 & .027 & .343 & 99.811 \\
\hline 7 & .015 & .187 & 99.998 \\
\hline 8 & .000 & .002 & 100.000 \\
\hline
\end{tabular}

TABLE III. ROTATION COMPONENT MATRIX.

\begin{tabular}{|c|c|c|}
\hline \multirow{2}{*}{ Index } & \multicolumn{2}{|c|}{ Common Factor } \\
\cline { 2 - 3 } & 1 & 2 \\
\hline Return on net assets & .137 & .176 \\
\hline Return on total assets & .158 & .125 \\
\hline Sales income & .202 & -.218 \\
\hline Net profit & .199 & -.022 \\
\hline Total profit & .200 & -.023 \\
\hline Net assets & .199 & -.069 \\
\hline $\begin{array}{c}\text { Average growth rate of sales revenue for the } \\
\text { last three years }\end{array}$ & .010 & .469 \\
\hline $\begin{array}{c}\text { Average growth rate of net profit for the last } \\
\text { three years }\end{array}$ & -.083 & .469 \\
\hline
\end{tabular}

Based on the data in the annual report of ten liquor enterprises on December 31, 2011, SPSS software has been used to do the correlation analysis of the primary data corresponding to the indexes listed above. We can find that the correlation coefficients of these indexes are all very big so that it is very suitable for us to evaluate the competitiveness of liquor enterprises by using factor analysis method. By standardizing and orthogonal rotating the primary data, we can get the eigenvalue and contribution rate of variance of the principal components, as shown in Table II.

According to the principle that the eigenvalue should be larger than one, we can be sure that two common factors should be extracted. From the rotating component matrix table as shown in Table III, the first six indicators are dominated by Common Factor 1, which can be generalized to be scale and profitability index. And the last two indicators are dominated by Common Factor 2, which can be called growth index.

These eight indexes are set to be $x_{1}, x_{2} \ldots x_{8}$ in turn. And the score of competitiveness is represented by $F$, so the score of each common factor will be $F_{i}, i=1,2$. 
According to the score coefficient matrix of each index, we have

$F_{1}=0.137 x_{1}+0.158 x_{2}+\ldots-0.083 x_{8}$

TABLE IV. COMPETITIVENESS SCORE OF THE 10 LIQUOR ENTERPRISES.

\begin{tabular}{|c|c|c|c|c|c|c|}
\hline $\begin{array}{c}\text { Liquor } \\
\text { Enterprise }\end{array}$ & $F_{1}$ & Rank & $F_{2}$ & Rank & $F$ & Rank \\
\hline Wu liang ye & 1.193 & 2 & -.238 & 7 & .688 & 3 \\
\hline $\begin{array}{c}\text { Gui zhou } \\
\text { mao tai }\end{array}$ & 1.845 & 1 & -.440 & 8 & 1.048 & 1 \\
\hline Jiu gui jiu & -.955 & 9 & .960 & 2 & -.376 & 6 \\
\hline $\begin{array}{c}\text { Lu zhou lao } \\
\text { jiao }\end{array}$ & .512 & 4 & .088 & 5 & .339 & 4 \\
\hline $\begin{array}{c}\text { Shan xi fen } \\
\text { jiu }\end{array}$ & -.288 & 6 & .597 & 3 & -.043 & 5 \\
\hline $\begin{array}{c}\text { Yang he gu } \\
\text { fen }\end{array}$ & .618 & 3 & 1.737 & 1 & .780 & 2 \\
\hline $\begin{array}{c}\text { Lao bai gan } \\
\text { jiu }\end{array}$ & -.917 & 8 & .202 & 4 & -.525 & 8 \\
\hline $\begin{array}{c}\text { Shun xin } \\
\text { nong ye }\end{array}$ & -.706 & 7 & -.325 & 9 & -.741 & 10 \\
\hline $\begin{array}{c}\text { Shui jing } \\
\text { feng }\end{array}$ & -.223 & 5 & -.629 & 10 & -.510 & 7 \\
\hline $\begin{array}{c}\text { Tuo pai she } \\
\text { dei }\end{array}$ & -.077 & 10 & .050 & 6 & -.659 & 9 \\
\hline
\end{tabular}

$F_{2}=0.176 x_{1}+0.125 x_{2}+\ldots+0.469 x_{8}$

$F=0.66250 F_{1}+0.22770 F_{2}$

Thus, we can get the final result of the competitiveness score of the ten liquor enterprises by calculating the data in detail, which has been shown in Table IV.

From the data in Table IV, we can notice that the scores of Wu Liang Ye, Yang He Shares and Gui Zhou Mao Tai are much higher than that of the other enterprises, which show that these three liquor enterprises have strong competitiveness. Although the growth indexes of Gui Zhou Mao Tai and Wu Liang Ye are not so good, but they still get such good results. All these depend on the high price brought about by the brand effect which finally leads to their strong profitability. For the other enterprises such as Jiu Gui, Tuo Pai She De and Lao Bai Gan, they have been developing faster in the last three years, so their growth indexes are good. But their competitiveness scores are relatively lower, just because they have got lower scores on scale index and profitability index. Generally speaking, liquor enterprises have been developing faster for the recent three years. Both profitability and scale of the liquor enterprises have been greatly improved.

\section{CONCLUSIONS}

In China, the development of liquor industry has changed so much. The internal industrial structure has begun to change. On one hand, the low-end market of liquor industry has begun to decline, one the other hand, the scale of high-end liquor market has made a spurt of progress. With the increase of liquor market scale and the changes of internal structure, a large number of liquor enterprises has come to the fore. $\mathrm{Lu}$ Zhou Lao Jiao, Yanghe River Shares, Shui Jing Fang, and some other liquor enterprises have developed to be the new forces that can compete against the old overlord of the liquor market such as Gui Zhou Mao Tai and Wu Liang Ye. But at the same time, with the market scale becoming stable gradually, the intense competition in the liquor industry will heat up. The old overlord such as Mou Tai and Wu Liang Ye will actively seize the new market on the basis of stabilizing the current market. And the new forces such as Lu Zhou Lao Jiao and the Yanghe River Shares will also inevitably try to seize the new market for its own development. So the serious competition cannot be avoided. If the liquor enterprise wants to survive in the fierce competition, it must own enough competitiveness.

From the analysis above, we can see that the profitability index and scale index have a big impact on the competitiveness of the liquor enterprises. This reflects an important feature of China's liquor industry which is that the brand effect being established for a long time is very important for the development of liquor enterprises. And the development of liquor enterprise has good continuity.

The competitiveness of enterprise is a complex issue affected by various factors. Moreover, the competitiveness of enterprises itself is lying in the dynamic and changing process. Therefore, it should be acknowledged that no one can accurately measure the competitiveness of enterprises without any doubt and then rank them. The method used for evaluating the competitiveness of enterprises should be improved gradually. We should not only use the method of economics, management and statistical analysis, but also use that of sociology, consumer psychology and other disciplines to study the competitiveness of enterprise. Only by doing so can the true state of the competitiveness of enterprises be accurately reflected. And then we can make a more realistic evaluation.

\section{ACKNOWLEDGMENTS}

The research work was supported by the scientific research promotion project of Northeast Dianli UniversitySoft Science, Humanities and Social Sciences Special Assistance Scheme under Grant No. 201311.

\section{REFERENCES}

[1] Da, C., Zhiming, Y., Evaluation of the scientific and technological competitiveness of the city in Zhejiang province based on factor analysis method. Journal of Jiaxing University, 2012.

[2] Xiaoqun, X., Application of Modern Statistical Analysis Method. China People University Press, 2007

[3] Qiang, L., Genwen, C., Multivariate statistical analysis on the evaluation of enterprise competitiveness. Enterprise Management, 2006

[4] Yuezheng, S., Tao, L., The evaluation method and empirical study on the competitiveness of large enterprises in China. Statistical Research.

[5] Jinchang, Z., Theory and Methods on the Evaluation of International Competitiveness. Beijing Economic Science Press, 2002. 
[6] Dali, H., Enterprise Competition Theory. Beijing Economic Management Press, 2001.

[7] Andrew E., Douglas S., West firm survival and chain growth in a privatized retail liquor store industry. Review of Industrial Organization, 32(1), 2008.

[8] Davies B., Competitive retail marketing. Journal of Retailing and Consumer Services, 2(1), 1995.

[9] Siegel Michael, Dejong William, Albers Alison B., et al., Differences in liquor prices between control state-operated and license-state retail outlets in the United States. Addiction (Abingdon, England), 2012.

[10] Rabah Amir, Imperfect competition, integer constraints and industry dynamics. International Journal of Industrial Organization, 25(2), 2006.

[11] Evert-Jan Visser, Peter Langen, The importance and quality of governance in the Chilean wine industry. GeoJournal, 65(3), 2006.

[12] Blake, Cary, Texas wine industry: Storied past and future growing pains. Western Farm Press, 31(16), 2009. 